\title{
CIP法とSMAC法に基づく平面 2 次元 氾濫流モデルの構築 \\ DEVELOPMENT OF DEPTH-AVERAGED INUNDATION FLOW MODEL BASED ON CIP METHOD AND SMAC METHOD
}

\author{
川崎浩司 1 - 小野稔和 2 - Napaporn PIAMSA-NGA ${ }^{3}$ - 熱田浩史 4 - 中辻啓二 5 \\ Koji KAWASAKI, Toshikazu ONO, Napaporn PIAMSA-NGA, Hiroshi ATSUTA and \\ Keiji NAKATSUJI
}

1 正会員 博(工) 大阪大学助手 大学院工学研究科土木工学専攻（广565-0871 吹田市山田丘2-1）

2正会員 修(工) 前田建設工業株式会社（テ355-0127 埼玉県比企郡吉見町大字大和田外地内）

3 学生会貝 工修 大阪大学 大学院工学研究科土木工学専攻（T565-0871 吹田市山田丘2-1)

4 学生会貝 学 $(I)$ 大阪大学 大学院工学研究科土木工学専攻 (T565-0871 吹田市山田丘2-1)

5 正会員 工博 大阪大学教授 大学院工学研究科土木工学専攻（T565-0871 吹田市山田丘2-1）

\begin{abstract}
Damage by flood inundation has often occurred in recent years even in urban areas, where water management systems are controlled properly. Advance provision of useful information such as hazard map and evacuation routes to the peripheral people is considered to be necessary in order to prevent and minimize the damage. Development of inundation flow numerical model is, therefore, required to predict flood inundation areas precisely.

In the present study, a depth-averaged flood inundation flow model in the Cartesian coordinate system is developed using a CIP method and a SMAC method. The validity of the model was verified by comparing the computed results with existing numerical and experimental ones in the one-dimensional and horizontally two-dimensional fields. As a result, the model was confirmed to be consistent with the existing numerical schemes and be able to reproduce the laboratory experiment with high accuracy.
\end{abstract}

Key Words : depth-averaged inundation flow model, CIP method, SMAC method, Cartesian coordinate system

\section{1.はじめに}

近年, 洪水汇濫による被害は, 治水・利水整備が充実 している都市域においても頻発している．洪水汇濫によ る被害を最小限に抑えるためには，ダムや堤防などの治 水施設の整備といったハード面のみならず，地域住民へ の有用な情報となるハザードマップや洪水時の避難経路 などのソフト面も強化する必要がある. したがって，地 形条件が複雑な都市域や山地河川にも精度高く対応でき る汇濫流モデルを構築し, 洪水による汇濫域を精緻に予 測・把握することが重要である。そのため，今まで， 様々な汇濫流数值モデルが提案されてきた. それらを大 別すると, デカルト座標系, 一般曲線座標系, 非構造格 子に基づく汇濫流モデル，そして市街地の道路網をネッ トワーク化して 1 次元解析法を適用する街路ネットワー
クモデルなどとなる11. 川池ら吕も指摘しているように, 各種モデルには一長一短があり, 研究対象地域の地理状 態, さらにはどのような汇濫現象を精度良く解析すべき かを考慮しながら, 数值モデルを選定することが必要で あるといえる.

著者ら゙は, 現在, タイ・チャオプラヤ川流域を対象 に洪水汇濫と地下水の関連性を究明するため, 地下帯水 層への浸透を考慮した洪水汇濫一地下水結合モデルを構 築し, その妥当性を検討している. しかし, 同モデルで は汇濫流モデルに簡易な数值モデルを用いており, 計算 精度の面に関しては不十分であると認識している. 今後, チャオプラヤ川流域の地理条件を考虑した長期問の洪水 汇濫と地下水の諸特性を議論する際, より精度の高い氾 濫流モデルを導入する必要がある.

そこで, 本研究では, 洪水汇濫一地下水結合モデルで 用いている 3 次元地下水有限差分モデルMODFLOW ${ }^{3)}$ と 
の結合の簡便さを考慮しつつ, さらに複雑な計算アルゴ リズムを伴わない汇濫流モデルとして, 高精度移流計算 スキームCIP (Cubic Interpolated Propagation) 法とSMAC

（Simplified Marker And Cell）法に基づくデカルト座標 系平面 2 次元汇濫流モデルを構築する. そして, 既往の 計算・実験結果と比較しながら，その妥当性を検証する.

\section{CIP法とSMAC法に基づく氾濫流モデル}

\section{（1）基礎方程式}

基礎方程式は水深方向に積分された平面 2 次元浅水流 方程式である. 式(1)は連続式を, 式(2), 式(3)はそれぞ れ $x, y$ 方向の運動量方程式を示す.

$$
\begin{aligned}
& \frac{\partial H}{\partial t}+\frac{\partial(U H)}{\partial x}+\frac{\partial(V H)}{\partial y}=0 \\
& \begin{aligned}
\frac{\partial(U H)}{\partial t}+ & +\frac{\partial\left(U^{2} H\right)}{\partial x}+\frac{\partial(V U H)}{\partial y} \\
& =-g H \frac{\partial\left(H+z_{b}\right)}{\partial x}-\frac{g n^{2} U \sqrt{U^{2}+V^{2}}}{H^{1 / 3}} \\
\frac{\partial(V H)}{\partial t} & +\frac{\partial(U V H)}{\partial x}+\frac{\partial\left(V^{2} H\right)}{\partial y} \\
& =-g H \frac{\partial\left(H+z_{b}\right)}{\partial y}-\frac{g n^{2} V \sqrt{U^{2}+V^{2}}}{H^{1 / 3}}
\end{aligned}
\end{aligned}
$$

ここで, $H$ は水深, $U, V$ は,$y$ 方向の断面平均流速, $g$ は重力加速度, $n$ はManningの粗度係数, $z_{b}$ は地盤高, $t$ は時間である.

\section{（2）計算アルゴリズム}

本モデルでは, 基礎方程式(1)〜(3)を, 時間分離解法 により, 移流段階（式(4)～式(6)） と非移流段階（式(7) 〜式(9)）の 2 つ段階に分離して計算を行う.

\section{移流段階}

$$
\begin{aligned}
& \frac{\partial H}{\partial t}+U \frac{\partial H}{\partial x}+V \frac{\partial H}{\partial y}=0 \\
& \frac{\partial U}{\partial t}+U \frac{\partial U}{\partial x}+V \frac{\partial U}{\partial y}=0 \\
& \frac{\partial V}{\partial t}+U \frac{\partial V}{\partial x}+V \frac{\partial V}{\partial y}=0
\end{aligned}
$$

非移流段階

$$
\begin{aligned}
& \frac{\partial H}{\partial t}=-H\left(\frac{\partial U}{\partial x}+\frac{\partial V}{\partial y}\right) \\
& \frac{\partial U}{\partial t}=-g \frac{\partial\left(H+z_{b}\right)}{\partial x}-\frac{g n^{2} U \sqrt{(U)^{2}+(V)^{2}}}{(H)^{4 / 3}} \\
& \frac{\partial V}{\partial t}=-g \frac{\partial\left(H+z_{b}\right)}{\partial y}-\frac{g n^{2} V \sqrt{(U)^{2}+(V)^{2}}}{(H)^{4 / 3}}
\end{aligned}
$$

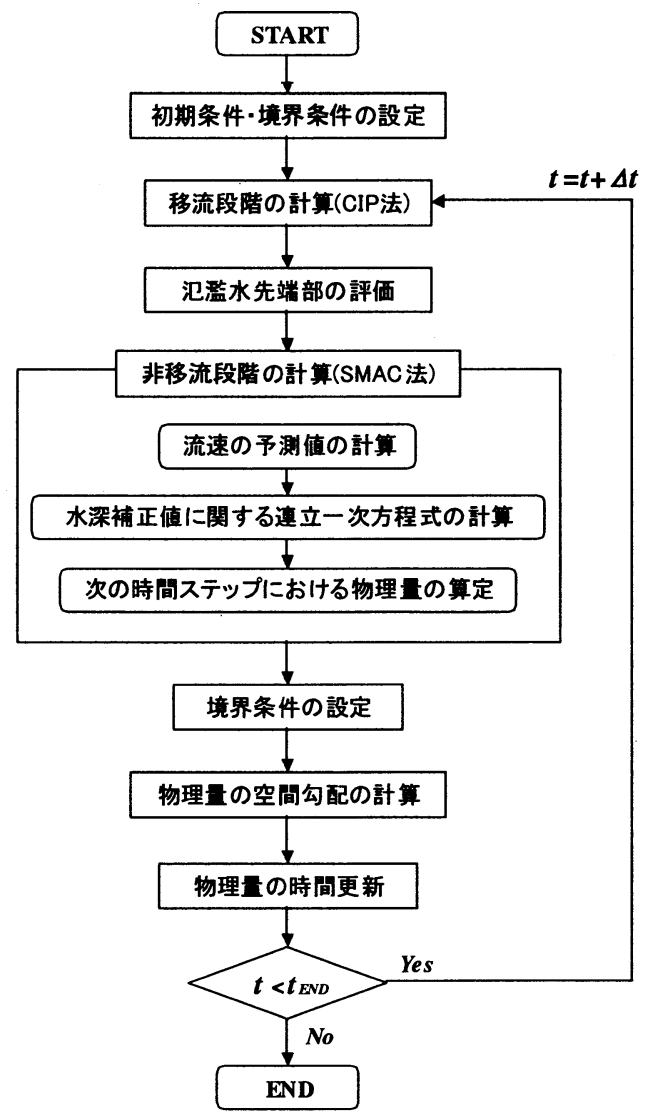

図-1＼cjkstart氾濫流モデルの計算フローチャート

ここで, 移流段階の計算には, Yabe and Aoki ${ }^{4)}$ が開発し たCIP法を採用した. CIP法は, 格子点間の物理量を 3次 関数で補間し連続条件に物理量とその 1 階微分值を用い て物理量の移流計算を行う手法であり，抎散の激しい場 においても物理量の移流を高精度に評価可能である. 一 方, 非移流段階に対しては, 後述するとおり, 水深の時 間変化量を陰的に解析するSMAC法を用いて計算した. なお，差分格子にはスタッガード格子を使用した.

図-1に本モデルにおける計算フローチャートを示す. まず初期条件，境界条件を設定し，CIP法を用いて移流 段階の計算を行う. 次のステップでは, 後で述べるとお り，汇濫水先端部を評価し，SMAC法を用いて非移流段 階を解析する. 最後に, 境界值の再設定, CIP法で必要 となる物理量の空間勾配を求め, 次の時間ステップにお ける物理量を算定する．この一連の計算過程を時間ス テッン゚ごとに繰り返すことにより，汇濫流の時系列計算 を行うことが可能となる.

\section{（3）SMAC法による非移流段階計算}

SMAC法5) とは, 次の時間ステップの物理量 $\phi^{n+1}$ を直接 解くのではなく, 運動方程式の差分化に流速の予測值を 導入し, 既知量 $\phi^{n}$ と次の時間ステップの未知量 $\phi^{n+1}$ の変 化量 $\delta \phi\left(=\phi^{n+1}-\phi^{n}\right)$ を求めることにより, 時系列計算を行 う手法である. 具体的な式の導出は以下のとおりである. 
まず，式(7)〜式(9)を以下のように離散化する.

$$
\begin{aligned}
\frac{H^{n+1}-H^{*}}{\Delta t}= & -H^{*}\left(\frac{\partial U^{n+1}}{\partial x}+\frac{\partial V^{n+1}}{\partial y}\right) \\
\frac{U^{n+1}-U^{*}}{\Delta t}= & -g \frac{\partial\left(H^{n+1}+z_{b}\right)}{\partial x} \\
& -\frac{g n^{2} U^{*} \sqrt{\left(U^{*}\right)^{2}+\left(V^{*}\right)^{2}}}{\left(H^{*}\right)^{4 / 3}} \\
\frac{V^{n+1}-V^{*}}{\Delta t}= & -g \frac{\partial\left(H^{n+1}+z_{b}\right)}{\partial y} \\
& -\frac{g n^{2} V^{*} \sqrt{\left(U^{*}\right)^{2}+\left(V^{*}\right)^{2}}}{\left(H^{*}\right)^{4 / 3}}
\end{aligned}
$$

ここで，上付き $* n, n+1$ はそれぞれCIP法による移流 段階計算後の既知量, $n$ ステップ後の既知量, $n+1$ ステッ プ後の未知量を示し,$\Delta t$ は時間ステップ間隔である.

しかし, 式(10)〜式(12)からわかるように, 右辺にも 時刻 $n+1$ ステップの未知量を含んでいるため, 陽的に物 理量を算定することができない，そこで，式(13), 式 (14)に示すように, 移流段階で得られた物理量を用いて, 流速の予測值 $\tilde{U}, \tilde{V}$ をまず陽的に求める.

$$
\begin{aligned}
& \frac{\tilde{U}-U^{*}}{\Delta t}=-g \frac{\partial\left(H^{*}+z_{b}\right)}{\partial x}-\frac{g n^{2} U^{*} \sqrt{\left(U^{*}\right)^{2}+\left(V^{*}\right)^{2}}}{\left(H^{*}\right)^{4 / 3}} \\
& \frac{\tilde{V}-V^{*}}{\Delta t}=-g \frac{\partial\left(H^{*}+z_{b}\right)}{\partial y}-\frac{g n^{2} V^{*} \sqrt{\left(U^{*}\right)^{2}+\left(V^{*}\right)^{2}}}{\left(H^{*}\right)^{4 / 3}}
\end{aligned}
$$

ついで, 式(11), 式(12)から式(13), 式(14)をそれぞれ 差し引くことにより, 式(15), 式(16)を得る.

$$
\begin{aligned}
& \frac{U^{n+1}-\tilde{U}}{\Delta t}=-g \frac{\partial \delta H}{\partial x} \\
& \frac{V^{n+1}-\tilde{V}}{\Delta t}=-g \frac{\partial \delta H}{\partial y}
\end{aligned}
$$

ここで, $\delta H$ は水深補正值 $\delta H=H^{n+1}-H^{*}$ を示す.

式(15), 式(16)を式(10)に代入することにより，水深補 正值 $\delta H$ に関する連立一次方程式(17)が導出される.

$$
\begin{aligned}
\frac{\partial^{2}(\delta H)}{\partial x^{2}}+\frac{\partial^{2}(\delta H)}{\partial y^{2}}= & \frac{1}{g H^{*}(\Delta t)^{2}} \delta H \\
& +\frac{1}{g(\Delta t)}\left(\frac{\partial \tilde{U}}{\partial x}+\frac{\partial \tilde{V}}{\partial y}\right)
\end{aligned}
$$

最終的に, 式(17)から水深補正值 $\delta H$ を求めることによ り, 次の時間ステップでの物理量を算定することが可能 となる. なお, 本研究では, ILUCGS (Incomplete LU decomposition Conjugate Gradient Squared）反復解法包を採 用して, 式(17)を解いた.

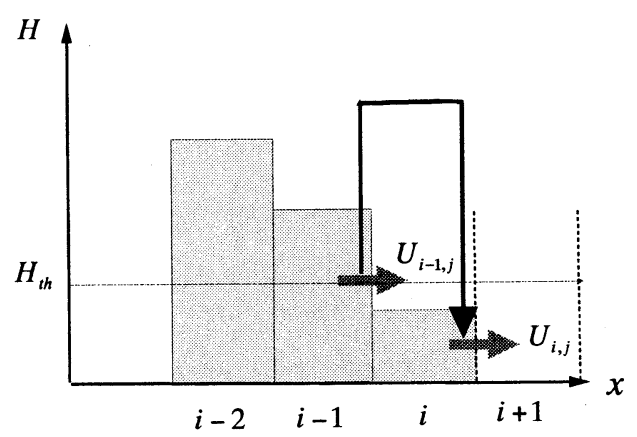

図-2＼cjkstart汇濫水先端部での取り扱いの一例

\section{（4）氾濫水先端部での取り扱い}

汇濫水先端では, 隣り合う計算格子のいずれかに水が 存在し他方で水が存在しない水深の不連続部となる. そ のため, 汇濫水先端部の取り扱いには留意する必要があ る. 本研究では, 図-2に例示するように, 䦭值法により 氾濫水先端部を取り扱った. まず移動限界水深を $H_{t h}$ と すると（本論文では， $H_{i h}=1 \mathrm{~mm}$ と設定）, 図-2では $H_{i-2, j}$, $H_{i-1, j}$ が $H_{t h}$ よりも大きく, $H_{i, j}, H_{i+1, j}$ がこれを満たしていな い. ゆえに, 汇濫水先端の境界は $H_{i-1, j}$ と $H_{i, j}$ の間にあると 判断される. なお, 移流段階計算後の点 $(i, j)$ の水深 $H_{i, j}^{*}$ が $H_{t h}$ よりも小さい場合には, 計算の発散を防ぐために, 式(13), 式(14)の右辺第 2 項の底面摩擦項を0として計算 した. また，氾濫水の先端部を滑らかに表現するために， $H_{i-1, j} \geqq H_{t h}$ and $H_{i, j}<H_{t h}$ and $H_{i+1, j}<H_{t h}$ のとき, スリップ条件 として $U_{i, j}=U_{i-1, j}$ を課した. なお, $y$ 方向に対しても同様 に取り扱った.

\section{3. モデルの検証}

\section{（1） 1 次元段波問題}

不連続部を有する開水路非定常流の典型的な一例とし て，1 次元段波問題を取り上げる. 本節では, 特性曲線 法に基づく 1 次精度流束差分離法（FDS）, 特性曲線上 の関係式に高次精度TVDスキームを用いたTVD-MUSCL スキーム, MacCormack法，CIP法による各手法”の計算 結果と比較しながら, 本モデルの妥当性を検証する.

計算領域を $10.0 \mathrm{~m}$ ，メッシュ間隔を $0.01 \mathrm{~m}$ ，時間ステッ プ間隔を $\Delta t=0.01 \mathrm{~s}$ と設定した. なお，本モデルを除く各 手法では厳密に1次元計算を行っているが，本モデルで は奥行き方向に $3.0 \mathrm{~m}$ 設けて平面 2 次元計算を行った. なお，奥行き方向の流動が一様になるように敗壁におけ る流速境界条件はスリップ条件とした. また, 初期条件 として, 幅 $10.0 \mathrm{~m}$ の水槽の中央に仕切り板を設け，その 左半分, 右半分にはそれぞれ深さ $1.0 \mathrm{~m}, 0.4 \mathrm{~m}$ の水を静水 状態で配置した.

図-3(a)，(b)にそれぞれ計算開始後 $t=1.0 \mathrm{~s}$ と $t=3.0 \mathrm{~s}$ にお ける各手法の計算結果を示す。図中の実線が本モデルに よるものである. 図-3(a), (b)の両図より, 計算手法の 


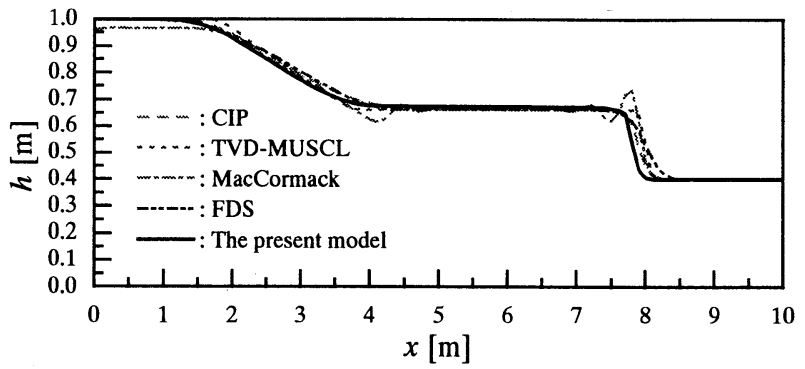

(a) $t=1.0 \mathrm{~s}$

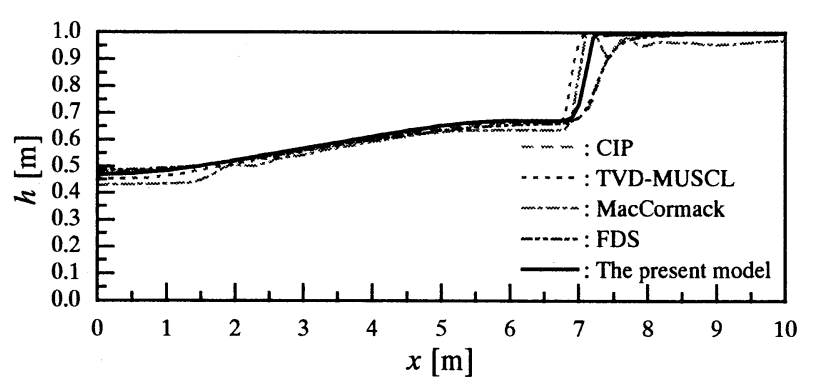

(b) $t=3.0 \mathrm{~s}$

図-3 1 次元段波問題

違いに関係なく, 計算開始後, 急激な水深変化を伴う段 波が発生している. 図-3(a)をみると，MacCormack法に よる水面形状は $x=4 \mathrm{~m}, 8 \mathrm{~m}$ 付近でアンダーシュート, オーバーシュートが生じているが, その他の手法では顕 著な差違は認められない, 一方, 段波が右端の壁に衝突 し跳ね返つた後の水面形状を表す図-3(b)では, 図-3(a) の計算結果と異なり, 段波前部付近で各手法に違いが現 れ，本モデルは各手法の計算結果の間にある. 定量的な 評価はしていないが, 本モデルは, 段波つまり水深の不 連続部を有する表面流の 1 次元数值解析において, 他の 高次精度のスキームと比較しても, 適度な計算精度を有 しかつ安定に時系列計算を行うことができるといえる.

\section{（2） 1 次元水柱崩壊問題}

汇濫流が水のないドライベッド上を進行する現象に対 する本モデルの妥当性を調べるために, 中山ら ${ }^{8)}$ が実施 した 1 次元水柱崩壊現象の計算結果と比較検討する. 計 算条件として, メッシュ間隔を $1.0 \mathrm{~m}$, 時間ステップ間隔 を $\Delta t=0.1 \mathrm{~s}$ とた. また, 前節と同様, 計算領域に奥行 きをもたせ，スリップ条件を㘗に課すことにより， 1 次元計算を模擬した.

図-4(a)に本モデルによる水柱崩壊シミュレーション結 果の一例を示す. なお, 図中の点線は初期の水面形状で あり, $x=0 \sim 100 \mathrm{~m}$ の範囲に高さ $1 \mathrm{~m}$ の水塊を配置し, $x$ $=100 \sim 200 \mathrm{~m}$ では水深が $0 \mathrm{~m}$ の汇濫原とした. また, 一点 鎖線と実線は計算開始後 $t=20 \mathrm{~s}$ での計算結果であり, 前 者は汇濫水先端部において流速の境界条件にスリップ条 件を課していない場合で, 後者は前章で説明したスリッ プ条件を課した場合である. スリップ条件下での計算結

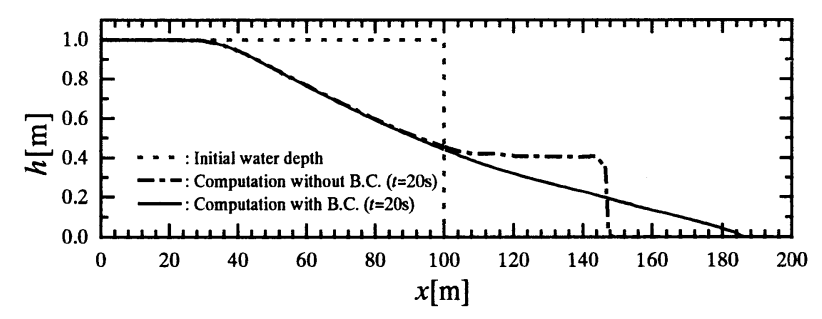

(a) 本モデルによる計算結果

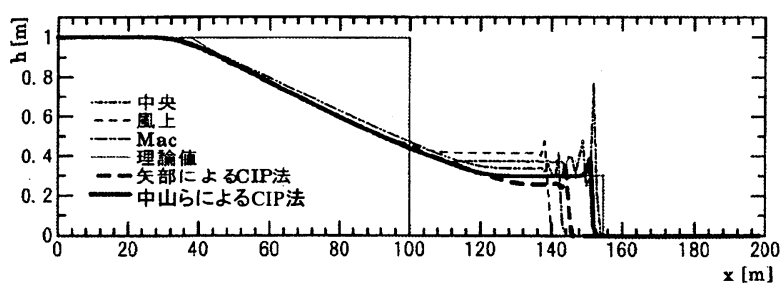

(b) 中山らによる計算結果)

图-4 1 次元水柱崩壊問題

果をみると, 汇濫水先端部の水面形状が滑らかに変化し ていることが確認できる. 一方, スリップ条件を課して いない場合, 前節で述べたような先端部が切り立つ段波 が発生している. このことから, 汇濫水先端部の取り扱 い方法の差異により, 計算結果が異なることが理解でき る. なお, 汇濫水先端部における流速境界処理について は引き続き検討する必要があるが，本論文では，ドライ ベッド上を進行する表面水の先端部境界として, 暫定的 にスリップ条件を課すことにした.

図-4(b)に中山らが実施した 1 次元水柱崩壊問題の計算 結果の引用を示す. 図中には, 中山らによるCIP法以外 にも, 中央差分, 風上差分, MacCormack法, 矢部らの CIP法の計算結果も同時に図示している. ここで, 図中 の中山らによるCIP法と矢部によるCIP法の差違として, 前者は計算の不安定性が生じさせないように運動方程式 中の移流項に対してのみCIP法を用いているが，後者は 運動方程式中の移流項のみならず連続式にもCIP法を採 用している点である. 本モデルは, 連続式と運動方程式 の移流段階に対してCIP法を適用しているため, 矢部に よるCIP法と類似しているが，移流段階と非移流段階の 計算手順が反対であること, さらに非移流段階での計算 方法が違うことから, 異なる数值モデルである.

図-4(b)に示す中山らのCIP法による計算結果を詳細に みると, 表面水の先端部において急激な水深増加, つま りオーバーシュートが発生している. 一方, 図-4(a)の本 研究で構築した数值モデルは, 急激な水深変化を伴うこ となく, 安定に計算が行われていることが確認できる.

さらに, 矢部によるCIP法では, 明らかに水塊の総量が 減少し質量が保存されていないが，本モデルでは質量の 保存が厳密に満たされており, 本モデルの有用性, 妥当 性が検証される. 

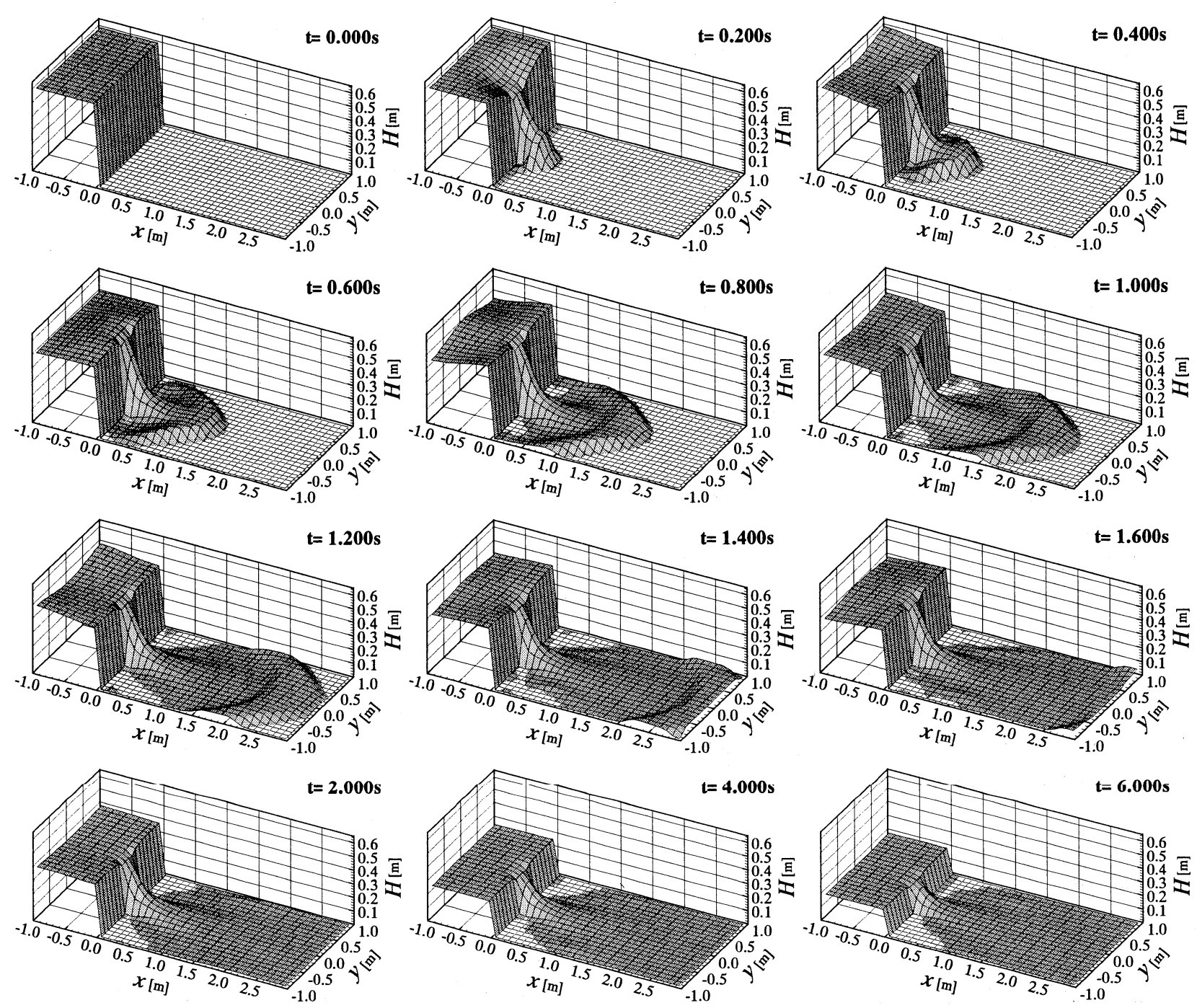

図-5＼cjkstart貯水池の部分決壊シミュレーション

\section{（3）平面 2 次元貯水池部分決壊問題}

本節では, Fraccarollo and Toro ${ }^{9}$ が実施した, 貯水池が 部分的に決壊したときの汇濫水挙動に関する水理実験と 比較することにより, 平面 2 次元場に対する本モデルの 妥当性, 有用性を定量的に検証する.

貯水池が部分的に決壊したときのシミュレーション結 果を図-5に図示する. 初期状態として, 同図の $t=0.000 \mathrm{~s}$ に示すように, 左側に貯水槽（長さ1m, 奥行き $2 \mathrm{~m}$ ）, 右側に汇濫原（長さ $3 \mathrm{~m}$, 奥行き $2 \mathrm{~m}$ ）があり, 貯水槽の 初期水深は0.6mで, 汇濫原は水の存在しないドライベッ ドである. また, $x=0 \mathrm{~m} に は$ 水槽と汇濫原を仕切る壁が あり, 中央部- $0.2 \leqq y \leqq 0.2$ の範囲には幅 $0.4 \mathrm{~m}$, 高さ $0.6 \mathrm{~m}$ の決壊部がある. Fraccarollo and Toroによる水理実験で は, 汇濫原の側方および下流端には取水するための横樋 と水槽が設置されており，数值計算ではそれを模擬する ために側方および下流端の境界条件を開境界とした. な お，計算全領域は，水理実験と同様， $4.0 \mathrm{~m} \times 2.0 \mathrm{~m}$ であり， $x$ 方向, $y$ 方向のメッシュ間隔をともに $0.1 \mathrm{~m}$, 時間ステッ プ間隔を0.01sとした. また, 粗度係数nはFraccarollo and
Toroの論文に明示されていなかったため, ここでは $n=0$ と設定した. 図-5をみると, 貯水池から流出する水が決 壊部を中心に段波を形成しながら円弧状に広がっていく 様子，また汇濫原の側方および下方境界が開境界である ため汇濫水が領域外部へと流出していく様子が認められ る. 一方, 貯水池における水深の時空間分布に着目する と, 決壊部 $y=0$ を中心とした静振を伴いながら, 水深が 徐々に減少していることがわかる.

図-6に各測定点での水深の時間変化を示す. 図中の実 線は本モデルによる計算值, O印はFraccarollo and Toro による実験值であり, 図-7に水深の測定点を示す. 水理 実験では, 水深を圧力計で計測しているが, 一部の測定 点では波高計を用いている. そこで, 決壊部周辺の水深 に対しては波高計，それ以外では圧力計による実験值を 採用して, 計算結果と比較した.

各測定点における計算結果は実験值の傾向を良好に再 現していることがわかる. 計算開始後 $t=1 \mathrm{~s}$ までの急激な 水深変化についても, $4 \mathrm{~A}$ 以外の測点では, 計算結果は 概ね実験值と一致している. 図示していないが, 


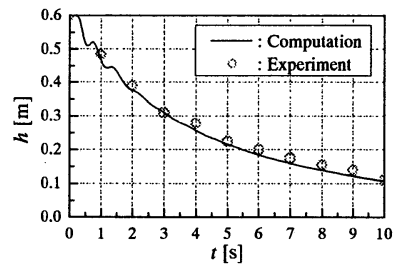

(a) 測点-5A

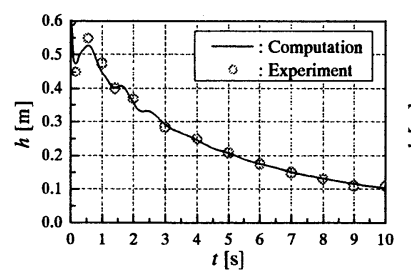

(c) 測点O

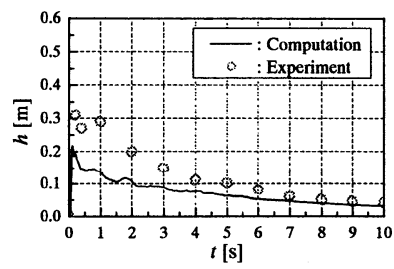

(e) 測点 $4 A$

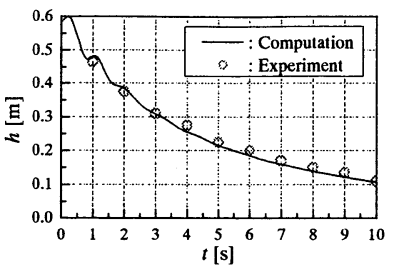

(b) 測点C

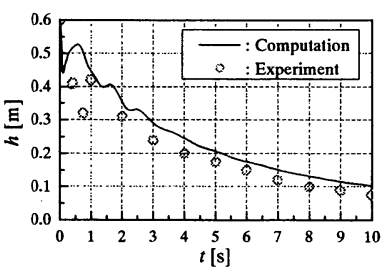

(d) 測点 4

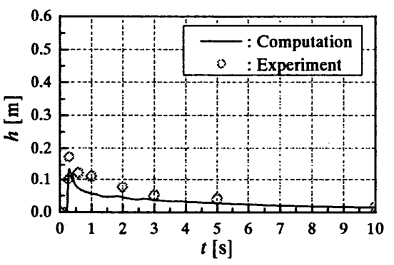

(f) 測点 $8 \mathrm{~A}$
図-6 各測定点における水深の時間変化

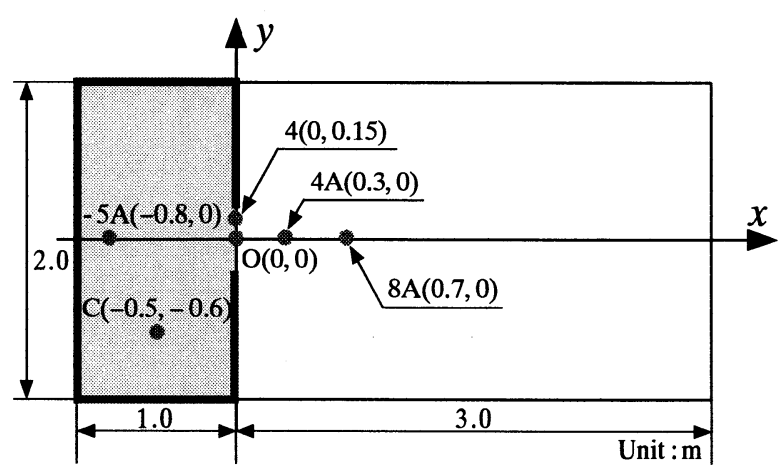

図-7 水深測定点

Fraccarollo and Toroが実施した計算結果と比較すると, 本モデルはFraccarollo and Toroのモデルでみられるよう な数值振動は発生しておらず，実験值にもより近い結果 であることを確認している.

アキレスら ${ }^{10}$ は，流束差分離法（FDS）に基づく 1 次 精度モデルRoe・Harten and Hymen（RHH）モデルと 2 次精度モデルLax-Wendroff ・ Roe - Seweby（LWRS）モ デルを包括した洪水流モデルを新たに提案し，本論文と 同様, Fraccarollo and Toroの実験值と比較検討している. 本モデルとアキレスらのモデルの計算結果を比較しても, 大きな違いは認められず, 両モデルは急激な水深変化を 伴う水理実験の結果を精度よく再現している. しかし, 両モデルとも, 決壊部直後の測点4Aに対しては, 計算 值と実験值の間に大きな差が生じている.これは，決壊 部周辺では, 鉿直方向加速度の影響が大きく, 静水圧近
似に基づく浅水流方程式モデルの適用限界を越えたため と考えられる. 以上のことをまとめると, 本モデルは, 実験結果を精度よく再現しているとともに, 既存の高精 度洪水汇濫モデルとほぼ同程度の計算精度をもっている ことが判明し, 本モデルの妥当性と有用性が平面 2 次元 場に対して検証されたと判断できる.

\section{4. おわりに}

本研究では, 汇濫水の動的挙動を高精度に数值解析す るために, CIP法とSMAC法に基づくデカルト座標系平 面 2 次元汇濫流モデルを構築した. そして, 急激な水深 変化を伴う段波問題, 貯水池決壊問題などに適用するこ とにより, 本モデルが安定かつ精度よく氾濫流を計算で きることを検証した. 今後, 堤防の越流効果を考慮する など, 更なるモデルの精度向上を図る予定である.

\section{参考文献}

1）川池健司, 井上和也, 林秀樹, 戸田圭一: 都市域の氾濫解 析モデルの開発, 土木学会論文集 No.698/II-58, pp.1-10, 2002.

2) 川崎浩司, 外木場康将, 中辻啓二 : チャオプラヤ川流域を 対象にした洪水氾濫一地下水結合モデルの構築, 水工学論 文集，第47巻，pp.883-888，2003.

3) Arlen W. Harbaugh, Edward R. Banta, Mary C. Hill, and Michale G. Mcdonald: MODFLOW-2000, The U.S. Geological Survey Modular Ground Water Model - User Guide To Modularization Concepts And Ground-Water Flow Process, U.S. Geological Survey Open-File Report 00-92, 2000.

4) Yabe, T. and T. Aoki : Universal solver for hyperbolic equations by cubic-polynomial interpolation I. One-dimensional solver, Computer Physics Communications, Vol.66, pp.219-232, 1991.

5) 数值流体力学編集委員会編 : 数值流体力学シリーズ1 非圧 縮性流体解析, 東京大学出版会, 330p, 1995.

6) 藤野清次, 張 紹良 : 応用数值計算ライブラリ 反復法の 数理, 朝倉書店, $140 \mathrm{p}, 1996$.

7）土木学会水理委員会基礎水理部会「水工学における計算機 利用の講習会」, 1999.

8) 中山恵介, 佐藤圭洋, 堀川康志 : CIP法を用いた浅水流方 程式の数值計算手法の開発, 水工学論文集 第42巻, pp.1159-1164, 1998.

9) Fraccarollo, L. and Toro, E.F. : Experimental and numerical assessment of the shallow water model for two-dimensional dambreak type problems, Journal of Hydraulic Research, Vol.33, pp.843-864, 1995.

10) アキレス クマールジャ, 秋山壽一郎, 浦 勝, 重枝末玲 : FDSを用いた洪水流の数值モデル, 土木学会論文集, No.656/II-52, pp.73-82, 2000.

(2003.9.30受付) 